\title{
PENGARUH SASTRA ISLAM ARAB TERHADAP KARYA TSAMARATUL IHSÃN FI WILÃDATI SAYYIDIL INSÃN KARYA SYEKH SULAIMAN AR-RASULI
}

\section{THE INFLUENCE OF ARABIC ISLAMIC LITERATURE ON TSAMARATUL IHSÃN FI WILÃDATI SAYYIDIL INSÃN BY SYEKH SULAIMAN AR-RASULI}

\author{
Chairullah \\ Universitas Islam Negeri Imam Bonjol Padang \\ Jl. Prof. Mahmud Yunus, Lubuk Lintah, Anduring, Kuranji, Kota Padang \\ E-mail: chairullah.ahmad@yahoo.co.id \\ Naskah diterima 14 September 2018, Diterima setelah perbaikan 21 Oktober 2018, \\ Disetujui untuk dicetak 28 November 2018
}

\begin{abstract}
Abstrak
Secara historis karya sastra Islam Melayu tidak terlepas dari pengaruh karya sastra Islam Arab, karena islamisasi di Nusantara membawa pengaruh terhadap berbagai aspek. Namun, apakah pengaruh yang diberikan oleh sastra Islam Arab membuat sastra Islam Melayu dipandang sebagai terjemahan dari karya sastra Islam Arab. Seperti sebuah karya yang berjudul Tsmaratul Ihsan yang berisikan tentang riwayat hidup Nabi, di mana jauh sebelum karya ini muncul telah banyak karya-karya Arab berbicara tentang tema yang sama, di antaranya kitab Barzanji yang digunakan oleh mayoritas masyarakat Nusantara sebelum abad ke 20. Tulisan ini merupakan suatu upaya untuk mebuktikan bahwa karya sastra melayu Islam yang lahir di Nusantara dalam bentuk syair atau nazam bukanlah saduran dan terjemahan utuh dari sastra Arab karena karya sastra melayu Islam memiliki karakteristik yang khas dan bersifat lokal dan juga diwarnai oleh kreatifitas penulisnya. Untuk melihat keotentikan karya ini akan digunakan teori interteks.
\end{abstract}

Kata Kunci: Sastra Islam Arab, Sastra Islam Melayu, Tsamaratul Ihsan

\begin{abstract}
Historically Malay Islamic literary work was inseparable from the influence of Arabic Islamic literature because Islamization in the archipelago had an influence on various aspects. However, whether the influence given by Arabic Islamic literature makes Malay Islamic literature seen as a translation of Arabic Islamic literature. Like a work entitled Tsmaratul Ihsan which contains the life history of the Prophet, where long before this work appeared, many Arabic works talked about the same theme, including the Barzanji book that was used by the majority of the Archipelago before the 20th this writing is an attempt to prove that Islamic Malay literary works born in the archipelago in the form of poetry or Nazam are not complete adaptations and translations of Arabic literature, because literary works with Islamic Malay have
\end{abstract}


characteristics that are distinctive and local and also colored by the creativity of the author. To see the authenticity of this work, the intertext.

Keywords: Arabic Islamic Literature, Malay Islamic Literature, Tsamaratul Ihsan.

\section{PENDAHULUAN}

Pengaruh sastra Arab terhadap sastra Melayu di Nusantara ditandai oleh masuknya agama Islam. Sebelum membahas lebih lanjut tentang pengaruh sastra Arab terhadap sastra Melayu di Nusantara, perlu juga dibahas sedikit tentang masuknya Islam ke Nusantara. Terjadi perbedaan pendapat tentang masuknya Islam ke Nusantara di kalangan sejarawan, namun beberapa bukti menjelaskan bahwa Islam telah masuk ke wilayah Nusantara pada abad $7 \mathrm{M}$ yang dibawa oleh orang Arab.

Hal ini terdapat dalam catatan sejarah Tiongkok yang menyebutkan pada pertengahan kurun yang ketujuh, terdapatlah sebuah kerajaan bernama Holing, dan sebuah Negeri bernama Cho-p'o. Rajanya ialah seorang perempuan bernama Si-mo. Dalam sejarah Tiongkok ini juga dijelaskan bahwa pada tahun 674-675 bangsa Ta-Cheh melawat ke Negeri Holing, hendak berhubungan dengan Raja perempuan Si-mo, supaya perniagaan kedua negeri ramai. Bangsa Ta-Cheh itu adalah bangsa Arab, sebab Ta-Cheh itu ialah nama yang diberikan orang Tiongkok kepada bangsa Arab Pada zaman-zaman itu, sedangkan Kerajaan Holing ialah Kerajaan Kalinga, yang memang pernah berdiri di Jawa Tengah (kata setengah penyidik) dan di Jawa Timur (kata setengah penyidik) pada pertengahan kurun abad ketujuh, dan memang ada seorang Ratu yang bernama Sima atau Simo, sedangkan Cho-Po adalah tanah "Jo-wo" (Hamka, 1963, 9).

Pengaruh Islam di Nusantara sangat terlihat jelas pada abad ke 15-16 M, hal ini dibuktikan dengan berkembangnya ajaran Islam serta beberapa tradisi Arab yang mempengaruhi Islam di Nusantara karena memang sampainya Islam ke Nusantara adalah atas jasa pedagang Arab. Diantara pengaruh tersebut dapat dilihat dalam tradisi sastra Melayu berbentuk Puisi atau Syair yang berasal dari bahasa arab yaitu syi'ir. Syi'ir adalah suatu kalimat yang sengaja disusun dengan menggunakan irama dan sajak yang mengungkapkan tentang khayalan atau imajinasi yang indah (Hamid, 1995: 13).

Selain syi'ir ada juga istilah nazham yang mana juga mengandung sebuah kalimat yang disusun dengan menggunakan irama dan sajak. Namun yang membedakan antara syi' ir dan nazham adalah unsur khayal. Nazham tidak memiliki unsur khayal, malah sebaliknya nazham lebih mengandung unsur realita atau ilmu pengetahuan (Rauf, 2009: 114-129).

Puisi atau syair lahir di Nusantara pada abad $16 \mathrm{M}$. Sebelumnya suatu puisi yang persis memenuhi syarat untuk disebut sebagai syair tidak terdapat di dalam sastra lisan Melayu atau bangsa-bangsa lain di Nusantara. Namun contoh puisi tertua ditemukan dalam karya Hamzah Fansuri seorang penyair besar Sufi yang hidup dalam pergantian abad ke 16 M, dan mungkin sekali dialah bapak dari genre ini, dalam kitabnya Asrār al-'Arifīn ia menerangkan tentang bentuk syair yang secara tidak langsung menjadi bukti bahwa syair menjadi sebuah genre baru semasa hidupnya itu. Beberapa ilmuwan terdahulu seperti A. tew dan Naqib menganggap syair Melayu merupakan pengaruh dari puisi Arab dan Persi, karena syair Melayu yang berpola aaaa mirip dengan ruba'i Parsi yang sangat terkenal (Braginsky, 1998:226-227). 
Sastra Melayu yang muncul di Nusantara pada awalnya hanya berbentuk folklor dan prosa. Genre sastra berupa syair belum ditemui pada saat itu, bahkan di masa peralihan sastra Hindu-Buddha kepada sastra Islam masih saja dalam wujud prosa (hikayat-hikayat), perubahannya itu hanya nampak dari segi isi sastra itu sendiri (Fang, 2011: 179-180). ${ }^{1}$

Seiring perkembangan Islam di Nusantara, daerah Minangkabau juga menjadi salah satu wilayah islamisasi. Perkembangan Islam secara signifikan baru terlihat setelah kepulangan seorang ulama asal Minangkabau yang bernama Syekh Burhanuddin dari Aceh. Di Aceh Syekh Burhanuddin belajar kepada Syekh Abdurauf berbagai macam disiplin ilmu baik ilmu bahasa, hukum Islam, tasawuf dan lain sebagainya (Basyir, 2008: 26). Setelah sampai di Minangkabau Syekh Burhanuddin mendirikan surau sebagai basis pendidikan (Azra, 2003: 9), melaui muridmuridnya Islam disebarkan ke berbagai pelosok Minangkabau.

Sastra Melayu dalam bentuk syair pertama kali ditemukan di Aceh yaitu pada karya Hamzah Fansuri (Braginsky, 1998: 449). Struktur syairnya itu dikenal dengan ruba'i, syair Melayu dengan konstruk ruba'i juga berkembang dan banyak ditemukan di Minangkabau. Hal ini menandakan bahwa syair dengan konstruk ruba'i itu telah mempengaruhi tradisi tulisan di Minangkabau.

Bukti lain bahwa karya-karya sastra Hamzah Fansuri mempengaruhi karya-karya sastra di Minangkabau adalah dengan ditemukannya beberapa salinan dari karya-karya Hamzah Fansuri di Minangkabau, seperti sebuah manuskrip yang ditulis oleh Syamsuddin Sumatrani yang berisikan tentang syarah dari ruba'i Hamzah Fansuri. ${ }^{2}$ Ini membuktikan bahwa karya sastra Hamzah Fansuri juga telah mempengaruhi konstruk intelektual di Minangkabau.

Syair-syair atau nazham yang lahir di Minangkabau berfungsi sebagai media untuk menyampaikan ajaran-ajaran Islam agar mudah dipahami, seperti kisah-kisah yang awalnya lahir dalam bentuk prosa Arab kemudian direformulasi menjadi syair dalam bahasa Melayu semisal: Kisah Nabi Wafat dan Fathimah ${ }^{3}$, Kisah Nabi Hafat dan Hamzah, Kisah Ratap Fatimah", Kisah Nabi Mi'raj dan lain sebagainya.

Jika dilihat dari segi isi, karya-karya sastra yang lahir di Minangkabau sebelum abad XX berisi tentang ajaran-ajaran tasawuf dan hikayat-hikayat yang mengandung akhlak. Namun, setelah terjadi beberapa arus pembaharuan di Minangkabau substansi dari karya sastra itu sendiri

\footnotetext{
${ }^{1}$ Sastra zaman peralihan adalah sastra yang lahir dari pertembungan sastra yang berunsur Hindu dengan pengaruh Islam. Dengan kata lain, sastra yang khas Hindu, seperti Hikayat Sri Rama, walaupun mengandung unsur-unsur Islam, tidak dianggap sebagai sastra peralihan. Ciri yang lain dari sastra zaman peralihan ialah bahwa sastra zaman peralihan biasanya mempunyai dua judul, satu judul Hindu dan satu judul Islam. Seringkali judul Islam adalah judul yang lebih dikenal daripada judul Hindunya.

${ }^{2}$ Dalam pembukaannya dikatakan "wa ba' dh dan kemudian darinya maka Syekh Syamsuddin bin 'Abd Rahimahullah peri menyatakan berbuat sharh ruba'i Hamzah Fansuri” kitab ini ditulis pada tahun 1019 H/ 1610 M.

${ }^{3}$ Karya ini ditemukan di Simpang Tonang Pasaman dalam bentuk manuskrip yang juga memuat syair Hamzah Fansuri dengan menggunakan kertas Eropa, meskipun tidak memiliki kolofon dari segi watermarknya naskah ini ditulis pada abad 18 M. Karya ini hanya menceritakan tentang proses wafatnya Nabi beserta Fatimah anak Nabi.

${ }^{4}$ Kisah ratap Fatimah ini menceritakan tentang kesedihan Fatimah saat ditinggal pergi oleh Nabi Muhammad saw. Kisah ini biasanya dibacakan saat ada acara kematian, seiring berjalannya waktu kisah ini juga berpindah dari tradisi masyarakat ke surau. Untuk lebih jelas baca Zuriati, Nazam Ratap Fatimah : Dari Rumah Duka ke Surau, Sari vol 25, 2007, 263-278
} 
ikut berubah, bahkan pada awal abad ke XX seiring dengan munculnya gerakan pembaharuan muncul pula berbagai media cetak dan sastra dalam bentuk syair menjadi salah satu ciri yang harus ada dari setiap karya yang pada awal abad ke XX.

Salah satu karya yang muncul pada awal abad ke-20 adalah kitab Tsamaratul Ihsn fi Wiladtil Sayyidil Insn yang ditulis oleh Syekh Sulaiman ar-Rasuly. Kitab ini berisikan tentang kisah hidup Nabi Muhammad saw, kitab ini ditulis dengan bahasa Melayu dengan aksara Arab Melayu dalam bentuk prosa. Untuk karya Arab sendiri yang berisikan tentang riwayat hidup Nabi Muhammad juga telah banyak berkembang di Minangkabau sebelum abad XX dan masih eksis hingga abad ke XX, karya-karya tersebut seperti Kitab Barzanji dan Saraful Anam yang umumnya digunakan oleh masyarakat Minangkabau ketika perayaan hari Maulid Nabi. Karya ini ditulis dalam bentuk prosa dan umumnya yang paling banyak digunakan oleh masyarakat Minangkabau adalah kitab Barzanji.

Penelitian ini bertujuan untuk melihat secara mendalam karya Tsamaratul Ihsn dan membandingkannya dengan kitab yang juga membicarakan tentang riwayat Nabi Muhammad seperti Barzanji atau Saraful Anam. Apakah kitab Tsamaratul Ihsan merupakan terjemahan dari kitab Barzanji atau Saraful Anam, atau sebuah karya baru yang diciptakan oleh Syekh Sulaiman ar-Rasuli lewat kepiawaiannya dan kreatifitasnya sebagai seorang ulama terkemuka di Minangkabau saati itu yang bersumber dari wawasan dan bacaan yang luas dari berbagai kitab sirah yang ada di dunia Islam.

\section{METODE PENELITIAN}

Pengaruh sastra Islam Arab terhadap sastra Islam Melayu berdasarkan kitab Tsamaratul Ihsn fi Wildati Sayyidil Insn milik Syekh Sulayman ar-Rasuli akan dilihat dengan menggunakan pendekatan interteks menurut Julia Kristeva, yang mengatakan bahwa munculnya teori interteks sebenarnya dipengaruhi oleh hakikat teks yang di dalamnya terdapat teks lain. Hal ini mengisyaratkan bahwa unsur teks yang masuk ke teks lain itu dapat saja hanya setitik saja. Jika kemungkinan unsur yang masuk itu banyak, berarti telah terjadi resepsi yang berarti. Jika dalam suatu teks terdapat berbagai teks lain berarti teks sastra tersebut disebut karnaval. Teks yang lahir kemudian hanya mosaik dari karya sebelumnya. Mosaik tersebut ibarat bahan yang terpecahpecah, terpencar-pencar, sehingga pengarang berikutnya sering harus menata ulang ke dalam karyanya. Dari ini akan muncul sebuah karya sastra yang merupakan transformasi teks lain (Endraswara, 2008: 131-132).

Dengan menggunakan studi interteks ini akan dilihat transmisi gagasan dalam konteks "Sirah nabaw". Apakah gagasan sastra Islam Melayu milik Syekh Sulaiman ar-Rasuli merupakan saduran dari sastra Islam Arab, atau sebuah karya baru dengan gagasan yang orisinil. Orisinal bukan berarti menolak sesutau yang lain, atau tidak berinteraksi sama sekali dengan sesuatu yang lain. Orisinal bukan berarti tidak memanfaatkan yang lain, bahkan orisinal bisajadi meniru. Orisinalitas tidak diwariskan, tetapi dikreasikan. Ia bukan substansi yang tetap, melainkan kekuatan yang bergerak. Apalagi perbedaan waktu, kawasan dan sosio kultural tempat di mana sebuah karya sastra lahir adalah faktor yang tidak bisa diabaikan dalam melihat orisinalitas gagasan (Adonis, 2003 : 141). Berdasarkan ini orisinalitas gagasan merupakan gagasan yang tidak sunyi dari gagasan lain yang lahir sebelumnya. 


\section{PEMBAHASAN}

\section{Sastra dan Agama}

Sastra sebagai sebuah tradisi pada masyarakat Arab telah hadir sebelum kemunculan Islam di Jazirah Arab. Sastra yang muncul sebelum datangnya Islam disebut dengan sastra Jahili, dan di sinilah dimulainya awal periodesasi sastra Arab yang diperkirakan telah ada 150 tahun sebelum kedatangan Islam (al-Iskandari dan 'Inani, 1978: 10). Pada periode ini kesusastraan yang berkembang banyak adalah syi ' ir (syair). ${ }^{5}$ Bangsa Arab mengubah syair sesuai dengan apa yang diserap oleh indera, perasaan, dan sesuatu yang terbesit di dalam hati mereka, sesuai dengan alam lingkungan mereka. Di antara tema-tema syair yang berkembang pada masa itu adalah al-Nasb atau disebut juga dengan $a l$-Tashbb. Syair ini berisi tentang kenangan pada sesorang wanita dengan berbagai keindahan fisiknya, kerinduan pada puing-puing rumah atau bangunan yang hancur dan mereka tinggalkan dengan senandung tentang unta, merpati, hembusan angin dan lain-lain (Hazbini, 2011: 39-40).

Selain itu, ada juga tema-tema syair lain pada zaman Jahili seperti, fakhr, madah, ratsa', hij', i'tidzr, washf, dan hikam wa amthal (al-Iskandari dan 'Inani, 1978: 46-50). Syair-syair Arab yang terkenal pada zaman Jahiliyah adalah syair-syair mu'allaqt yang berbentuk qasidah. Disebut mu'allaqt karena syair-syair tersebut digantungkan di dinding Ka'bah. Syair-syair mu' allaqat berbentuk qasidah panjang dengan tema yang beragam, di antaranya menggambarkan keadaan, cara dan gaya hidup orang-orang Arab. Selain mu' allaqat, syair-syair yang digantung itu juga disebut: al-sumut (kalung), al-mudzahhabt (yang ditulis dengan emas), al-qas'id almashhurat (ode-ode yang terkenal), al-sab‘u al-tiwal (tujuh buah yang panjang-panjang), alal-qas'id al-tis'u (sembilan ode), al-qas'id al-'ashr (sepuluh ode) (Sutiasumarga, 2001: 32). Syair-syair mu'allaqt ini dihasilkan oleh beberapa penyair ternama di zaman itu seperti, Umru' al-Qais, Zuhair bin Abi Sulma, Tharafah bin al-'Abd, Antarah, Amr bin Kulthum, Labid dan Thawilah al-Harith. ${ }^{6}$

Syair Arab pertama yang sampai kepada kita adalah syair milik Al-Anbari bin Amr bin Tamim, Muhalhil bin Rabi ‘ah at-Taghlibi al-Ruba‘i, Umru’ al-Qais dan penyair jahiliyah lainnya. Namun di antara mereka itu syair yang paling banyak sampai kepada kita adalah syair-syair milik Muhalhil (al-Faisal, 1405 H: 45).

\footnotetext{
${ }^{5}$ Sebagian pendapat juga ada yang mengatakan bahwa prosa lebih dahulu hadir dalam sejarah kesusastraan Arab dibandingkan syi'ir seperti yang diungkap oleh Ibn Rasyid bahwa asalnya bahasa dan ungkapan itu berbentuk prosa dan kemudian orang-orang arab membutuhkan lagu-lagu yang membicarakan budi pekerti, mengenang memori kehidupan dan sebagainya sehingga muncul wazn-wazn yang kemudian disebut dengan syair. Baca Husein al-Hajj Hasan, Adab al-'Arab fi 'Ashr al-J ahiliyyah (Beirut: t.p., 1990), 25

${ }^{6}$ Pembahasan lebih lanjut dalam kasus ini adalah penyangkalan beberapa sastrawan tentang keberadaan mu'allaqat yang digantungkan di Ka'bah ini. Mereka berpendapat bahwa berita yang sampai kepada kita tidak memiliki informasi yang jelas tentang cara menggantungkannya, waktunya, penulisannya atau orang yang memerintahkannya, kemudian pada masa dahulu Ka'bah pernah mengalami kerusakan dan kemudian diperbaiki pada masa Nabi Saw, namun tidak ada satupun yang menuturkan tentang mu'allaqat, kemudian orang-orang Arab tidak mungkin menodai Ka 'bah dengan kefasikan dan kemungkaran yang terdapat pada mu'allaqat, kemudian syair-syair yang baik dan berpengaruh terhadap orang-orang Arab cukup banyak, mengapa hanya mu'allaqat saja yang berpengaruh, dan terakhir andaikan ia digantung pada dinding Ka'bah, maka ia akan terkenal dan tidak mungkin menimbulkan perselisihan mengenai jumlahnya dan jumlah baitnya. Baca Abd al-Mun'im Khafaji, alSyi'ir al-J ahili (Beirut: Dar al-Kitab, 1973)
} 
Setelah Islam datang syair-syair Arab banyak digunakan untuk tujuan keagamaan, seperti sarana dakwah, penyebaran aqidah Islamiyah, sebagai alat kodifikasi ajaran dan ilmu agama Islam, untuk membangkitkan motivasi umat Islam dan untuk beramal saleh, menyampaikan mau'izhah hasanah, dan memuji Rasulullah Saw (Rauf, 2009: 8). Sejak masa inilah sastra Islam mulai muncul.

Kemudian Pada abad ke $2 \mathrm{H}$ sastra Islam menjadi lebih kaya. Hal ini dengan munculnya golongan atau sekte yang berupaya untuk menjauhkan diri dari urusan duniawi, hidup dalam kesederhanaan dan menyibukkan diri untuk melatih diri agar bisa menemukan jalan untuk dekat dengan Sang Pencipta. Mereka dikenal dengan Sufi. ${ }^{7}$ Tokoh sufi pertama yang mengemukan sebuah konsep agar bisa mendekatkan diri kepada Allah ialah Rab'ah al-'Adawyah dengan konsep al-Mahabbah al-Ilhiyah yaitu sebuah konsep tentang rasa cinta yang tulus kepada Allah Swt. Konsep ini adalah konsep awal dalam dunia tasawuf yang diperkenalkan oleh Rab'ah al-'Adawyah sehingga menjadikan ia sebagai seorang yang terhormat dalam dunia sufi (Schimmel, 2008: 38-39). Konsep mahabbah inilah yang kemudian melahirkan konsep-konsep sufistik lainnya yang bermacam-macam (Smith, 2010: 47). Rasa cintanya yang besar terhadap sang Khaliq kemudian diungkapkan oleh Rabi 'ah ke dalam untain syairnya seperti:

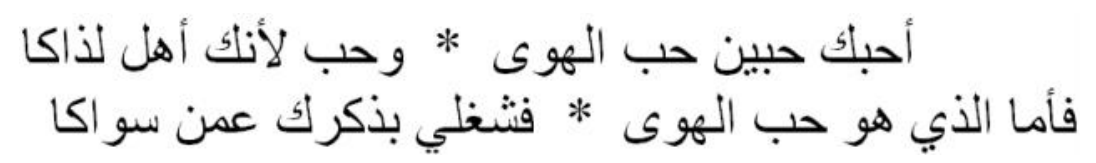

Aku mencintai Mu dengan dua macam cinta, cinta asmara * dan cinta karena Kau memang berhak dicintai.

Adapun bentuk cinta asmara pada-Mu * Aku hanya sibuk mengingat-Mu hingga aku lupa selain Diri-Mu (al-Khafj, tt: 202)

Bisa dikatakan bahwa sastra sufi atau sastra yang bertemakan tasawuf belum dikenal pada periode awal sejarah sastra Islam. Sastra sufi baru muncul sejak kehadiran Rabi 'ah beserta lantunan syairnya, sehingga sejak kehadirannya ini mulailah puisi dijadikan sebagai wahana ekspresi ajaran tasawuf (bandingkan dengan Salam, 2004: 28). Kemudian muncul juga tokoh lain dalam sastra ini seperti Dzunûn al-Misr (w.860M) dengan konsep al-ma'rifah nya yang bisa ia gapai melalui kecintaannya (mahabbah) yang besar kepada Allah sehingga dibukakanlah hijab yang menghalanginya dengan Tuhannya (Siradj, 2000: 10). Rasa cintanya kepada Allah untuk menggapai konsep ma'rifah itu kemudian ia gambarkan lewat syair-syairnya. ${ }^{8}$ Setelah itu muncul tokoh sufi besar lainnya dengan konsep rindu kepada Tuhannya yang disebut dengan

${ }^{7}$ Untuk istilah sufi ini sendiri begitu banyak pendapat yang muncul dalam rangka mendudukan asal usul kata sufi ini. Namun di antara ragam pendapat itu yang paling mendekati maksudnya ialah bahwa sufi berasal dari kata صـ في (shûf) yang berarti kain wol. Karena dalam sejarah tasawuf bagi orang yang ingin melalui jalan sufi, maka ia harus meninggalkan pakaian yang mewah dan diganti dengan pakaian sederhana yang dibuat dari bulu domba. Hal ini melambangkan kesederhanaan dan ketidak tergantungan dengan dunia yang penuh gemerlap. Baca Fauzi Faisal Bahreisy, Latha' if al-M inan: Rahasia yang M aha Indah (Jakarta: PT. Serambi Ilmu Semesta, 2008), 247. Kemduian Zaimul Am, Secret of The Secret: Hakikat Segala Rahasia Kehidupan (Bandung: PT. Serambi Ilmu Semesta, 2008), 183.

${ }^{8}$ Bait-bait syairnya ini dapat dilihat pada Muhammad Ibn Hasan Ibn 'Aqil Musa al-Syarif, Tasbih waMunajat wa Thana' 'ala Ardh wa al-Sama' (Riyadh: Dar al-Andalus al-Khadhra',2000),88 
syawqah yang dikemukakan oleh al-Junayd al-Baghdd (w.910M) (Shalikin, 2009: 9). Setelah itu muncul lagi seorang tokoh dengan paham al-hulûl nya, ia adalah Husayn ibn Manshur al-Hallj. AlHallj mengalami persatuan dengan Tuhannya, sehingga dalam syatahatnya ia melontarkan kata-kata "Ana al-H aqq" . Hal ini yang kemudian membuatnya dihukum gantung. Pengalaman yang ia dapatkan dan perasaan yang ia rasakan ketika ia menyatu dengan Tuhan kemudian ia ungkapkan pada bait-bait syairnya seperti :

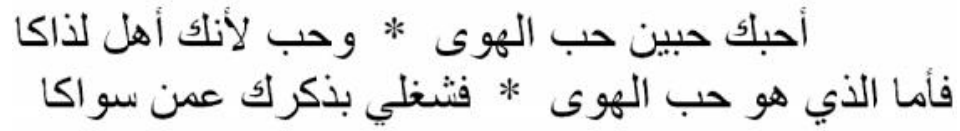

Aku adalah Dia yang kucintai, dan Dia yang kucintai adalah aku * Kami adalah dua jiwa dalam satu tubuh.

Jika engkau lihat aku, engkau lihat Dia * dan jika engkau lihat Dia maka kau lihat Kami (alJawar, 2006: 280) .

Kemudian setelah itu muncul seorang sufi terkemuka lainnya yaitu Muhyidn ibn 'Arab (1165-1240 M) yang terkenal dengan paham wujudiyahnya yang dikenal dengan wahdat alwujûd (Halligan, 2001: 275). Paham ini menegaskan bahwa alam merupakan manifestasi (tajalli) dari Tuhan. Alam merupakan bayangan dari Tuhan dan merupakan cerminan dari Tuhan. Wujud alam bergantung kepada wujud Tuhan, karena tanpa Tuhan bayangan tidak akan pernah ada. Meskipun bayangan yang ada pada alam ini banyak tetapi pada hakekatnya satu (Kartanegara, 2006: 7-8). Paham wujudiyah ini juga yang kemudian banyak mempengaruhi karya-karya dalam tema tasawuf di Nusantara, seperti Hamzah Fansuri, Abdurrauf dan lain-lain baik dalam bentuk syair maupun prosa. Abdurauf pernah mengungkap konsep yang sama dengan konsep wujudiyah Ibn Arab tersebut dengan istilah "syuhûd al-wahdah fi al-katsr (melihat yang satu pada yang banyak) dan syuhûd al-katsr fi al-wahdah (melihat yang banyak hilang di dalam yang satu). ${ }^{9}$

Berdasarkan hal tadi para kritikus sastra telah menggolongkan karakteristik karya sastra yang dianggap sebagai sastra sufi, di antaranya adalah berisikan pujian bagi Nabi dan doa (Khafaji, tt: 176-179). Karya-karya yang membicarakan pujian terhadap Nabi tersebut seperti Qasidah Burdah ${ }^{10}$ yang ditulis oleh al-Bushri $(608-696 \mathrm{H})$, kemudian kitab maulid yang berisikan

${ }^{9}$ Hal ini diungkap oleh Abdurauf dalam karyanya kifayat al-muhtajin. Dalam karyanya ini ia berusaha menjelaskan konsep wahdat al-wujud yang menjadi ikhtilaf. Dalam karyanya ini ia juga menjelaskan tentang tanzih dan tashbih yang mana dua pertentangan ini bisa dihubungkan, dan penghubung bagi tanzih dan tashbihitu ialah wahdat al-wujud. Meskipun penjelasan tentang tanzih dan tashbih ini sudah dijelaskan secara mendalam sebelumnya oleh Ibrahim al-Kurani yang merupakan guru Abdurrauf dalam karyanya ithaf al-Dhaki. Karya al Kurani ini telah dikaji secara dalam oleh Oman Fathurahman, Ithaf al-Dhaki Tafsir Wahdatul Wujud bagi Muslim Nusantara (Jakarta: Mizan dan EFEO, 2012).

${ }^{10}$ Penulisan Burdah ini berawal saat al-Bushiri mengidap sebuah penyakit (merasakan beberapa bagian tubuhnya tidak bisa bergerak), karena merasa tidak bisa melakukan pekerjaan seperti biasanya, maka dia berfikir untuk menyusun sebuah Qasidah. Setelah Qasidah itu selesai ditulisnya, ia memohon syafa'at kepada Allah atas Qasidah itu agar diberikan kesembuhan dengan cara mengulang-ulang melantunkan Qasidah tersebut sambil merenungkannya sampai ia menangis haru. Setelah itu dia tertidur, di dalam tidurnya dia melihat Nabi saw., lalu Nabi mengusap wajah al-Bushiri dengan tangannya yang mulia, sehingga dia merasakan kesejukkan. Setelah terbangun dari mimpi itu, al-Bushiri sembuh dari penyakit yang diidapnya. Baca Shafadi, al-Wafi bi al-Wafayat, (Beirut: Daar Ihya al Turas, 2000) Vol 3, 93-94 
tentang sirah Nabi yang mengandung makna pujian atau ta' zhim di dalamnya seperti Barzanji. Kitab Barzanji kemudian menjadi sebuah kitab yang sering dibaca dalam perayaan Maulid Nabi di Indonesia dan kitab ini adalah kitab yang paling populer di Indonesia di antara kitab-kitab maulid yang ada di Indonesia (Bruinessen, 1995: 97).

\section{Sastra Melayu dan Islam}

Sastra Melayu asli atau sastra tradisional ialah suatu golongan cerita yang hidup dan berkembang secara turun temurun dari suatu generasi ke generasi berikutnya. Istilah lain yang bisa digunakan untuk menyebut golongan karya sastra ini ialah cerita rakyat atau folklor. Disebut sebagai cerita rakyat karena cerita ini hidup di kalangan rakyat. Dalam golongan ini kita jumpai beberapa jenis karya sastra, seperti mantra, pribahasa, pantun, teka-teki, cerita binatang, cerita asal-usul, cerita jenaka, dan cerita pelipur lara (Djamaris, 1993: 15).

Sastra memiliki kedudukan yang cukup istimewa di dalam tradisi Melayu. Manusia, hewan dan burung-burung telah menjadi bahan karya sastra oleh pengarang Melayu. Tak hanya itu, berbagai misteri alam seperti gunung, sungai, batu dan pohon-pohon yang besar telah diceritakan di dalam karya sastra itu dengan menarik (Hamidi, 1988: 1). Sastra Melayu mengalami perkembangan dengan munculnya karya sastra Melayu yang dipengaruhi oleh Hindu. Pengaruh Hindu merupakan pengaruh asing pertama di Nusantara. Sejak abad I sudah ditemukan pengaruh Hindu di Nusantara. Hasil sastra Hindu yang terkenal seperti Ramayana, Mahabarata, dan Pancatantra yang di dalam sastra Melayu dikenal dengan Judul Hikayat Sri Rama, Hikayat Pandawa Lima, Hikayat Sang Boma (Djamaris, 1993: 16).

Sastra Melayu kemudian mendapat warna baru setelah masuknya Islam, namun sebelum sastra Melayu didominasi oleh Islam secara keseluruhan ada periodesasi sastra Melayu yang disebut dengan sastra zaman peralihan. Sastra zaman peralihan adalah sastra yang lahir dari pertambungan sastra yang berunsur Hindu dengan pengaruh Islam. Untuk mengetahui karya sastra yang tergolong sastra zaman peralihan ini amatlah sukar di antaranya adalah ditemukannya unsur Islam dalam sastra Melayu yang dianggap tua seperti Hikayat Sri Rama yang dalam salah satu versinya menceritakan bahwa Nabi Adam memberikan kekuasaan kepada Rawana yang sedang bertapa. Namun untuk menentukan sastra zaman peralihan dapat dilihat dari ciri-cirinya seperti:

- Tuhan yang dijunjung tinggi mula-mula adalah Dewata Mulia Raya atau Batara Kala kemudian diganti oleh Raja Syah Alam atau Allah Swt

- Sastra zaman peralihan biasanya mempunyai dua judul, satu judul Hindu dan satu Judul Islam. Seringkali judul Islamnya lebih dikenal dari pada judul Hindunya misalnya Hikayat Syah Mardan lebih dikenal daripada Hikayat Indra Jaya (Fang, 2011: 179-180).

Semakin lama unsur Islam semakin tebal dan sastra pada zaman peralihan ini berangsur menuju gerbang sastra yang dipengaruhi oleh Islam sepenuhnya. Sastra yang didominasi sastra pengaruh budaya lokal dan budaya india, mulai diperkaya oleh sastra yang berasal dari Negeri Islam, terutama Arab dan Parsi. Sastra Melayu secara tertulis mulai pada Zaman Islam dengan aksara Arab (Djamaris, 2004: 315). Tidak hanya segi tema dan isi yang dipengaruhi oleh Islam terhadap sastra Melayu, lebih dari itu Islam juga telah mempengaruhi struktur sastra melayu yang pada awalnya tidak mengenal istilah syair. Syair tertua atau pertama kali ditemukan dalam 
karya sastra melayu terdapat pada puisi karya Hamzah Fansuri. Dalam karya Hamzah yang berjudul Asrr al-Arifn ia menerangkan tentang syair yang secara tidak langsung menjadi bukti bahwa syair merupakan suatu genre baru semasa hidupnya itu. Syair berkembang dalam pengaruh puisi Parsi dan Arab di dalam kalangan Sufi (Bragansky, 1998: 226).

Struktur syair yang terdapat dalam karya-karya puisi Hamzah tadi kemudian menyebar ke pelosok-pelosok Nusantara, di antaranya di Minangkabau. Bersyair atau bernazam ${ }^{11}$ adalah salah satu corak yang ditemukan dalam manuskrip Minangkabau, ada beberapa syair yang ditulis di atas kertas yang cukup tua (kertas eropa) syair atau nazam itu seperti : nazam Fatimah dan Nabi Wafat, Nazam Tarekat Samaniyah dan Syair perahu karya Hamzah sendiri.

Jika dilihat tema-tema yang dibicarakan oleh karya-karya sastra berbahasa Melayu sebelum awal abad ke 20 maka dapat dipahami bahwa karya-karya itu lebih banyak berbicara tentang nasehat, ajaran dan sejarah atau kisah. Berbeda dengan karya-karya sastra yang kita jumpai pada awal abad ke 20, meskipun tidak terlepas dari tema-tema di atas karya-karya awal abad ke 20 juga diwarnai dengan tema-tema polemik sehingga memunculkan syair atau nazam satire dan apologetik.

\section{Gagasan Sastra Islam Arab Dalam Kitab Tsamaratul Ihsan}

Kitab Tsamaratul Ihsan adalah sebuah karya yang ditulis oleh Syekh Sulayman ar-Rasuly dalam merespon isu-isu tentang maulid Nabi di Minangkabau. Sebelum kitab ini ditulis telah terjadi perdebatan yang cukup panjang tentang permasalahan berdiri maulid ketika perayaan maulid Nabi. Permasalahan ini juga pernah menjadi salah satu tema dalam rapat ulama yang terjadi pada tahun 1919 M di Padang (Schrieke, 1973: 80-81). Kemudian pada tahun $1922 \mathrm{M}$ permaslahan ini sampai dibawa ke Makkah untuk menentukan hukum yang sebenarnya daripada melaksanakan perkara berdiri Maulid tersebut (Nur, 1991: 150-159). Dalam kitab Tsmaratul Ihsan, juga dijelaskan keputusan dari hasil rapat di Mekkah. Tidak hanya itu, Syekh Sulyman ar-Rasuly juga menjelaskan dalil-dalil tentang ke sunnahan berdiri saat sampai bacaan kepada Nabi dilahirkan dengan niat memuliakan Nabi.

Kitab Tsamaratul Ihsan selesai ditulis pada tahun 1923 M dengan bahasa Melayu dan aksara Arab Melayu. Kitab itu ditulis dengan bentuk syair atau nazam dengan sajak aaaa, dalam sastra Arab pola aaaa dikenal dengan istilah ruba'i. Kitab ini terdiri dari beberapa pasal :

\footnotetext{
${ }^{11}$ Pada prakteknya syair atau nazam tidak memiliki kriteria tersendiri dalam karya-karya yang ditemukan di Minangkabau. Dalam satu segi penulis menyebut syair dengan istilah nazam. Tidak ada perbedaan mendasar antara syair atau nazam dalam sastra Melayu di Minangkabau seprti terdapatnya perbedaan yang mendasar pada syair dan nazam dalam sastra Arab.
} 
1. Asal Makhluk

2. Berpindah Nur ke Punggung Adam

3. Aminah Kawin dengan Abdullah

4. Mimpi Aminah sembilan bulan

5. Khabar Abdullah

6. Kabar Asiyah dengan Maryam

7. Ajaib Nabi Zahir

8. Nan Menjawat Nabi dan ajaibnya

9. Kota Persi dan kantor Irak

10. Nama tempat Nabi Zahir

11. (....)pada hari nan ke tujuh

12. Nan menyusukan Nabi

13. Nabi lekas Gadang

14. Nabi berbedah

15. Cerita Halimah

16. Batu dan lainnya memberi salam kepada Nabi
17. Aminah ke kota Madinah

18. Wasiat Abdul Muthalib

19. Pasal ke kota Syam

20. Pasal ke tanah Syam

21. Pasal Nabi berniaga

22. Pasal Ka'bah rusak

23. Pasal menerima wahyu

24. Pasal orang beriman

25. Pasal Nabi sembahyang malam

26. Pasal mati Abi Thalib

27. Pasal Nabi mi'raj

28. Pasal Nabi mendakwakan jadi Rasul

29. Nabi ke Madinah

30. Pasar kafir Makkah memanggil(....)

31. Pasal kabar Madinah

32. Pasal Nabi sakit

Sedangkan kitab Barzanji hanya memiliki 11 sub bahasan dalam mengisahkan Nabi Muhammad saw, seperti :

1. Nasab Rasulullah

2. Perpindahan Nur

3. Kelahiran Nabi Muhammad saw

4. Keadaan Nabi sewaktu lahir

5. Peristiwa yang terjadi sewaktu Nabi telah lahir

6. Penyusuan Nabi

7. Sifat tubuh dan badan Nabi

8. Meninggalnya ibu dan kakek Nabi

9. Nabi sebagai seorang pedagang

10. Penyelesaian Nabi atas persoalan Hajar al-Aswad

11. Dipilihnya Nabi sebagai Rasul

12. Sahabat Nabi yang pertama

13. Peristiwa Isra' dan Mi'raj

14. Kisah Kaum Anshar

15. Nabi hijrah

16. Kesempurnaan Nabi sebagi seorang Rasul

17. Akhlak Nabi

Jika dilihat dari sub bahasan yang dipaparkan oleh kitab Thamaratul Ihsan dan kitab Barzanji maka terlihat jelas ada sub pembahasan yang sama, dan terlihat juga bahwa kitab Tsamaratul Ihsan lebih lengkap dan detail dalam memaparkan kisah Nabi Muhammad dibandingkan dengan kitab Barzanji. 
Untuk memastikan apakah sub bahasan yang sama antara Barzanji dan Tsamaratul Ihsan merupakan terjemah dari Barzanji atau bukan, akan kita lihat pada pembahasan perpindahan Nur.

\section{Tsmaratul Ihsan}

Wahai saudara dengarlah madah Menjadikan Adam setelah sudah Nur Muhammad jadilah pindah Dipindahkan Tuhan ada faedah

Ke punggung Adam pindah ke situ Malaikat sujud waktu itu Disuruh Allah Tuhan yang satu Masuk ke saruga itu waktu Segala malaikat tegak berdiri Di belakang Adam bers\}aflah diri Memandang Nur Muhammad jauhari Cahayanya lebih dari pada matahari Berkata Tuhan masa sekarang Malaikat berdiri maksudnya terang Melihat Nur hatinya girang Nur Muhammad penghulu orang

Adam berkata pada masa itu Wahai ya Allah Tuhan yang satu Nur Muhammad pindahkan tentu Ke hadapan hamba tarok ke situ

Wahailah Tuhan hamba bermadah Nur Muhammad jikalau pindah Ke hadapan hamba ada faedah

Malaikat melihat di hadapan sudah Nur Muhammad Tuhan pindahkan Di Kaning Adam Tuhan letakkan Malaikat di hadapan tetap melihatkan Kemudian itu Adam katakan

Wahai Tuhan Allah hamba berkata Nur Muhammad pindahkan nyata Supaya boleh di pandang mata Hamba melihat boleh serata Kemudian itu Nur berpindah Ditunjuk Adam bertempat sudah Malaikat dan Adam dapat faedah Melihat Nur hati tak gundah

\section{Terjemahan Barzanji}

Mereka adalah para pemimpin yang cahaya kenabian berjalan di garis-garis dahi mereka yang cemerlang. Dan jelaslah cahayanya (Nabi Muhammad) di dahi datuknya, Abdul Muththalib, dan anaknya, Abdullah. Ketika Allah Ta'ala menghendaki untuk menampakkan hakikatnya yang terpuji, dan memunculkannya sebagai jasmani dan ruhani dalam bentuk dan pengertiannya, Dia memindahkannya ke tempat menetapnya di kandungan Aminah AzZuhriyyah, dan Dzat Yang Mahadekat dan Maha Memperkenankan, mengkhususkannya (Aminah) menjadi ibu makhluk pilihan-Nya (Yusuf, 1991: 13-14). 
Yang Nur itu bertambah baiknya

Adam melihat sangat sukanya

Adam mendengar akan tasbihnya

Seterang-terang dengan nyatanya

Kemudian Nur berpindah lagi

Kepada Hawa jadi pergi

Adam melihat petang dan pagi

Di muka Hawa cahayanya tinggi

Cahayanya Nur serupa matahari

Adam melihat setiap hari

Suka dan rindu kedua diri

Pada muka hawa cahaya berdiri

Kemudian itu tidaklah lama

Hawa meanakkan Nabi utama

Nabi Shith itulah nama

Nur berpindah kesitu sama

Nur berpindah berulang-ulang

Dari muka Hawa jadilah hilang

Sampai kepada Shith rupa cemerlang

Adam berjanji sampai dibilang

Adam berjanji kita khabarkan

Dengan nabi Shith ulama katakan

Nur nan jangan disia-siakan

Kepada orang suci hendak letakkan

Kemudian itu selama masa

Nur berpindah senantiasa

Kepada orang baik saja dirasa

Begitu takdir $\mathrm{Tu}[\mathrm{h}]$ an yang esa

Nur berpindah selama zaman

Turun temurun takdir Rahman

Dari laki-laki orang yang beriman

Kepada perempuan orang budiman

Dari perempuan Nur berpindah

Dibawa laki-laki orang yang indah

Selama masa sampai wiladah

Begitu takdir hukuman sudah

Nur berpindah sangat lamanya

Sampai kepada nenek kandungnya

'Abd al-Muthalib itu namanya

Rupanya baik sangat indahnya

Masa di situ heranlah orang

Nur bertambah cahayanya terang

Di dalam kalam tidak terlarang

Walau ditutup cahaya benderang 
Kemudian Nur pindah pulalah

Kepada perempuan ibu 'Abdullah

Kemudian itu takdir Allah

Kepada 'Abdullah jadi pindahlah

'Abdullah itu bapak junjungan

Rupa yang baik larang bandingan

Besarnya lekas sukar tunangan

Umur sehari sebulan kegadangan

'Abdullah itu orang bangasawan

Rupanya tidak ada jodoan

Segala perempuan jadi tertawan

Tetapi tak untung tidak pertemuan

Wahai sahabat segala orang

Baik 'Abdullah sudahlah terang

Di tanah Arab jodonya larang

Cahayanya di kening amatlah

benderang

Pada masa itu dengarlah tuan

Zahirlah pula seorang perempuan

Perempuan jambang muda perawan

Amat mulianya lagi bangsawan

Perempuan bernama Siti Aminah

Berlangkah jahat belum pernah

Khulashah perempuan Makah

Madinah

Sifatnya baik lagi amanah (ar-Rasuli, 1923: 8-10).

Pada kisah ini dapat dilihat bahwa antara kitab Thamarah dan Barzanji ingin menceritakan bahwa Allah ingin memperlihatkan kebesarannya dengan menurunkan hakekat Nur yang mulia. Hanya saja dalam Barzanji dikatakan Allah memilih Abdul Muthalib sebagai wadah untuk proses transmisi Nur tersebut, sehingga tampak jelas pada dahinya. Kemudian Nur itu berpindak kepada Abdullah dan dari Abdullah kemudian berpindah kepada Aminah. Sedangkan dalam kitab Thamarah Allah memilih Adam sebagi wadah pertama untuk proses transmisi Nur yang ditujukan untuk Nabi Muhammad saw. Dari Adam Nur tersebut bertransmisi kepada Hawa dan dari Hawa kepada anak dan cucunya yang mulia dan terpilih pula, kemudian sampai kepada Abdul Muthalib, Abdullah dan Aminah. Dari hal ini terlihat jelas ada persamaan pembahasan antara Barzanji dan Tsamaratul Ihsan namun pembahasan yang diberikan oleh kitab Tsamaratul Ihsan lebih lengkap dibandingkan dengan Barzanji.

Setelah melihat persamaan dan perbedaan antar kitab Barzanji dan Tsamaratul Ihsan pada pembahasan perpindahan Nur. Sekarang akan dilihat pada pembahasan Nabi lahir antara kitab Barzanji dan Tsamaratul Ihsan : 


\section{Kitab Tsamaratul Ihsan}

Menjelang subuh pada akhir malam

Zahir Muhammad penghulu alam

Intan mustika permata nilam

Terang benderang tidaklah kalam

Di sini sunnat kita berdiri

Kirm ta'zhm hendak hadiri

Riya takabur jangan diberi

Harapkan pahala khaliq al-bari

Dalam berdiri baca pujian

Khusuk tawaduk hadir sekalian

Harapkan pahala dalam ujian

Tala'a al-badr awalnya bayan

Shallallhu 'ala M uhammad

Shallallhu 'alaihi wa sallam

Shallallhu 'ala M uhammad

Ya rabbi shalli 'alaihi wa sallim

Thala'a al-badr 'alaina

$M$ in tsaniyat al-wada'

Wajaba al-shukr 'alaina

Ma da'a lillahi da'

Ayyuha al-mab'udtsu fina

Ji'ta bi al-amr al-mutha'

Kun shafi'an ya habibi

Yaum hashr wa ijtima'

Shallallhu hu 'ala M uhammad

Shallallhu hu 'alaihi wa sallam

Shallallhu hu 'ala M uhammad

Ya rabbi shalli 'alaihi wa sallim

Nabi lah zahir pada itu masa

Menyalahi adat yang telah biasa

Sakit dan pedih tidak dirasa

Begitu takdir Tuhan kuasa

Perut Aminah dibelah Tuhan

Belah rahmat tidak kemarahan

Dibawah pusat Aminah tahan

Disitulah keluar Rasul pilihan

Di bawah pusat perutnya belah

Sakit dan pedih tidak adalah

Itu tandanya kekasihnya Allah

Junjungan alam di situ keluarlah

Nabi punzahir cahaya menyembur

Ke kiri ke kanan sampai mehambur

Sampai ke tanah Sham tidaknya kubur

\section{Terjemahan Barzanji}

Lalu Aminah merasakan sakitnya orang yang mau melahirkan, kemudian ia melahirkan beliau Nabi Saw dengan bercahaya yang cemerlang, sehingga memenuhi seluruh angkasa raya. Wajahmu bagaikan matahari yang menyinari, yang karenanya malam menjadi terang benderang. Malam kelahirannya bagi orang yang beragama menjadikan kegembiraan dan kemegahan pada hari siangnya. Kelahirannya merupakan hari kejayaan yang diperoleh Aminah, kejayaan yang mana belum pernah diperoleh wanitawanita lain. Aminah membawa kepada kaumnya, orang yang lebih utama daripada yang dikandung sebelumnya oleh Maryam yang perawan.

Hari kelahiran Nabi pada pandangan orang kafir merupakan suatu bencana dan malapetaka baginya. Terus-menerus kabar gembira memberitakan bahwa insan pilihan telah dilahirkan dan benarlah kegembiraan itu. Demikianlah, para imam yang memiliki riwayat dan pemikiran, memandang baik untuk berdiri ketika menyebutkan kelahirannya yang mulia. Maka kebaikanlah yang didapatkan orang yang penghormatannya terhadap Nabi SAW sampai ke puncak harapan dan tujuan. Beliau lahir dengan meletakkan kedua tangannya di atas tanah dengan mengangkat kepalanya ke langit yang tinggi. Dengan mengangkatnya itu beliau mengisyaratkan kepemimpinannya (atas makhluk) dan ketinggian (akhlaq)-nya. Beliau juga mengisyaratkan ketinggian derajatnya atas seluruh manusia. Dan sesungguhnya beliau adalah orang yang dicintai dan baik naluri dan perangainya. Ibunya memanggil Abdul Muththalib yang ketika itu sedang thawaf pada bangunan itu (Ka'bah). Lalu ia datang 
Mata memandang tidaklah subur Zahir junjungan setelah sudah Allahu akbar bacaan lidah gembira pula menjadi madah Riwayat begitu pindah berpindah Muhammad zahir intan biduri Abdul Muttalib khabar diberi Disuruh Siti Aminah Zuhri Seorang Rasul lekas be[r]lari

Abdul Muttalib ini waktu Sedangnya tawaf sudahlah tentu Rasul pun datang lekas ke situ Hatinya suka bukan suatu Abdul Muttalib sedang berapat Mereka tawaf khabar pun dapat Oleh sukanya badan terlompat Kepada Aminah datangnya cepat Abdul Muttalib sangat sukanya Mendapat kabar zahir cucunya Kepada Aminah segera datangnya Alhamdulillah kata lidahnya

Wahai saudara permata nilam Ditambah khabar u[m]pama ulam Adat orang Arab beranak malam Adat yang lama sebelum Islam Jikalau malam anak zahirnya Bangsanya quraysy tidak lainnya Anak ditutup dengan nyatanya Dengan periuk batu asalnya

Tatkala zahir junjungan kita Adat begitu dibuat nyata Dengan periuk ditutup serta Asal dari batu sudah dikata

Di bawah periuk Nabi berbedung $\mathrm{U}[\mathrm{m}]$ pama kepala di bawah tudung Menantikan tiba neneknya kandung Neneknya datang periuk kudungan Neneknya datang periuk belah Belahnya dua tiga bukanlah Cucu dilihat hati sukalah Belahan nyawa anak Abdullah Nabi dilihat oleh neneknya Mata terbuka sangat nyatanya $\mathrm{Ke}$ atas langit terus pandangnya segera dan memandangnya, dan ia memperoleh kegembiraan yang dicitacitakannya. Abdul Muththalib lalu memasukkannya ke Ka'bah yang cemerlang dan mulai berdoa dengan niat yang tulus (ikhlas). Ia bersyukur kepada Allah Ta'ala atas apa yang telah dianugerahkan dan diberikan kepadanya (Yusuf, 1991: 19-23). 
Lalunya isap ibu jarinya

Keluarlah laban dari ibu jari

Nabi mengisap Tuhan memberi

Kepada nenek isyarat diberi

Memberi salam rupanya diri

Neneknya suka serta hibah

Cucu dibawa masuk ka'bah

Kepada Tuhan tegak menyembah

Banyak doanya $\mathrm{u}[\mathrm{m}]$ pama lebah

Nenek mendoa khalish niatnya

Kepada Allah banyak syukurnya

Atas nikmat Nabi cucunya

Pemberian Allah gedang harganya

Abdul Muttalib sukanya nyata

Lebih mendapat gunung permata

Alhamdulillah lalunya kata

Akhirnya sanjung bukan semata

Waktunya zahirnya Tuan junjungan

Di atas bumi te[r]letak tangan

Sesudah dua lutut dalam pandangan

Serupa orang sujud menurut keterangan

Serupa orang sujud tangan dan kaki

$\mathrm{Ke}$ atas langit pandang mendaki

Memberi isyarat tanda laki-laki

Tuah dan penghulu akan didaki (ar-

Rasuli, 1923: 18-20)

Pada bagian ini dapat dilihat bahwa ketikaAminah melahirkan Nabi, maka saat itu terpancalah cahaya dan menyembur sehingga menerangi seluruh Alam. Dan pada saat ini lah di sunatkan berdiri bagi orang-orang yang membaca kisah ini. Kemudian Nabi lahir dengan meletakkan kedua tangan sambil memandang ke langit sebagai bukti kepemimpinannya dan ketinggian derjatnya daripada manusia diseluruh alam ini. Pada saat itu Aminah memberi tau Abdul Muthalib yang sedang melaksanakan tawaf. Mendengar kabar gembira ini Abdul Muthalib bergegas menuju Nabi Muhammad dan meninggalkan tawafnya. Abdul Muthalib langsung membawa Nabi Muhammad ke dalam Ka ‘bah dan mengucapkan rasa syukurnya kehadirat Tuhan dengan tulus dan ikhlas atas apa yang telah ia peroleh. Meskipun redaksinya sama namun ada beberapa perbedaan yang terdapat pada kitab Thamarah dan Barzanji yaitu; dalam Barzanji dijelaskan ada semacam tradisi Arab jika anak dilahirkan dan anak itu bersuku Qurais, maka anak tersebut akan ditutup dengan periuk yang terbuat dari batu. Hal ini masih diberlakukan ketika Nabi lahir, kemudian saat Abdul Muthalib datang dan melihat Nabi yang saat itu tengah menghisap ibu jarinya sambil memandang ke atas, dan dari ibu jarinya itu keluar air susu. Cerita yang seperti ini tidak terdapat dalam kitab Barzanji. 
Dari dua perbandingan tema di atas terlihat jelas ada persamaan antara kitab Barzanji dan Tsmaratul Ihsan. Namun kedua kitab ini juga memiliki banyak perbedan secara substansi. Meskipun demikian tidak dapat dipungkiri bahwa gagasan kitab Tsamaratul Ihsan tidak sunyi dari pengaruh gagasan kitab Barzanji sebagai sebuah kitab yang lebih dulu hadir dan digunakan oleh masyarakat khususnya di Minangkabau.

\section{PENUTUP}

Secara historis tidak dapat dipungkiri, bahwa sejak masuknya Islam ke Nusantara banyak mempengaruhi sosial kultural masyarakat di Nusantara khususnya Minangkabau. Di antara pengaruh tersebut terlihat jelas pada kesusasteraan Melayu. Ketika masa pra Islam gagasan yang terdapat pada sastera Melayu lebih dipengaruhi oleh hindu seperti hikayat Ramayana, Mahabarata, Pancatantra yang di dalam sastra Melayu dikenal dengan Judul Hikayat Sri Rama, Hikayat Pandawa Lima, Hikayat Sang Boma.

Setelah masuknya Islam gagasan sastra melayu mulai berubah dan mendapat warna yang baru dengan munculnya hikayat-hikayat yang Islami dan jenis sastra baru seperti syair dan nazam yang dimasa pra Islam tidak dikenal. Syair dan nazam kemudian memainkan peranan penting dalam karya intelektual di Nusantara khususnya Minangkabau. Salah satunya ialah kitab Tsamaratul Ihsan yang berisikan tentang riwayat hidup Nabi Muhammad. Sebelum kitab ini hadir telah ada kitab-kitab lain seperti Barzanji dan Syaraf al Anam yang berisikan tentang riwayat hidup Nabi yang digunakan oleh masyarakat Minangkabau disaat mengadakan perayaan maulid Nabi.

Kitab Tsamaratul Ihsan yang hadir belakangan bukanlah sebuah karya yang berdiri sendiri. Karya ini secara gagasan dipengaruhi oleh kitab-kitab terdahulu yang berisikan tentang riwayat Nabi. Salah satunya adalah kitab Barzanji, secara gagasan kitab Tsamaratul Ihsan dipengaruhi oleh kitab Barzanji dan Syaraf al-Anam sebagai kitab pendahulunya walaupun tidak secara keseluruhan. Meskipun dipengaruhi oleh kitab Barzanji dan Syaraf al-Anam yang berbahasa Arab, jelas kitab Tsamaratul Ihsan bukanlah saduran dan terjemahan dari kitab Barzanji, karena kitab Tsamaratul Ihsan juga mengadopsi riwayat-riwayat lain yang berbeda.

Dengan mengadopsi karya-karya lain dan mereformulasikannya kembali membuat kitab Tsamaratul Ihsan menjadi karya baru dan tersendiri dari karya-karya lainnya, sehingga kitab ini bisa dikatakan karya orisinil dari Syekh Sulaiman ar-Rasuli meskipun dipengaruhi oleh kitab Barzanji dan Syaraf al-Anam. 


\section{DAFTAR PUSTAKA}

Azra, Azyumardi. 2003. Surau, Pendidikan Islam Tradisional dalam Transisi dan Modernisasi. Ciputat: PT Logos Wacana Ilmu.

Adonis. 2003. Al-Tsābit wa al-Mutahawwil: Bahtsun fi al-Ibdā' wa al Itbā' 'Inda al-'Arab Juz 3. Beirut : Dār al-Sāqī.

Basyir, Damanhuri. 2008. Tradisi Kehidupan Agama di Aceh Abad XVII. Banda Aceh: Ar-Raniry Press,

Braginsky. 1998. Yang Indah, Berfaedah dan Kamal, Sejarah Sastra Melayu Dalam Abad 7-19. Jakarta: INIS.

Bahreisy, Fauzi Faisal. 2008. Latha'if al-M inan: Rahasia yang Maha Indah. Jakarta: PT. Serambi Ilmu Semesta.

Bruinessen, Martin van. 1995. Kitab Kuning: Pesantren dan Tarekat,Tradisi-tradisi Islam di Indonesia. Bandung: Mizan.

Djamaris, Edward. 1993. Menggali Khazanah Sastra Melayu Klasik. Jakarta: Balai Pustaka. 2004. Sastra Melayu Lintas Daerah. Jakarta: Pusat Bahasa.

Endraswara, Suwardi. 2008. Metodologi Penelitian Sastra; Epistemologi, Model, Teori, dan Aplikasi. Yogyakarta: Media Pressindo.

Fang, Liaw Yock. 2011. Sejarah Kesusastraan Melayu Klasik. Jakarta: Yayasan Pustaka Obor Indonesia.

Al-Faishal, Abd al-Aziz bin Muhammad. 1405 H. Al-Adab al-'Arabi wa Tarikhuhu. Riyadh: alMamlakah al-Arabiyah al-Su'udiyah.

Hadi, Syofyan. 2014. Sastra Arab Sufistik Nusantara; Orisinalitas Gagasan dan Stilistika Karya Syekh Isma'il al-M inangkabawi.Tangerang Selatan: Lembaga Studi Islam Progresif (LSIP).

Halligan, Fredrica R. 2001.'The creative Imagination of The Sufi Mystic, Ibn 'Arabi, International Journal of Religion and Health, Vol. 40, No. 2, Summer.

Hamid, Mas'an. 1995. Ilmu Arudl dan Qawaf. Surabaya:Al-Ikhlas.

HAMKA. 1963. Dari Perbendaharaan Lama. Medan : Maju.

Hasan, Husein al-Hajj. 1990. Adab al-'Arab fi 'Ashr al-J ahiliyyah. Beirut: t.p.

Hazbini. 2011. Kontroversi Puisi Sufi : Struktur dan Resepsi Puisi Ibn al-Farid. Bandung : Sastra Unpad Press.

al-Iskandari, Ahmad dan Mustafa 'Inani. 1978. al-Wasith fi al-Adab al-'Arabi wa Tarikhihi. Mesir: Dar al-Ma'arif.

al-Jawari, Ahmad 'Abd al-Sattar. 2006. al-Syi'r fi Baghdad Hatta Nihayat al-Q arn al-Tsalith al-Hijri. Beirut: al-Mu'assasat al-"Arabiyah li al-Dirasat wa al-Nashr.

Kartanegara, Mulyadi. 2006. Menyelami Lubuk Tasawuf. Jakarta: Erlangga.

Khafaji, Abd al-Mun'im. 1973. al-Syi'ir al-J ahili. Beirut: Dar al-Kitab.

Muhammad Nur, 1991. Gerakan Kaum Sufi di Minangkabau awal abad ke-20. Tesis tidak diterbitkan. Yogyakarta.

Rauf, Fathurrahman. 2009. Syair-syair Cinta Rarul: Studi Tahlily atas Corak Sastra Kasidah Burdah Karya al-Bushiry. Ciputat: Puspita Press.

Ar-Rasuli, Sulayman. 1923. Tsamaratul Ihsan fi Wiladatil Sayyidil Insan. Fort de kock: Mathba'ah alA'amiyah.

Ridha, Abdurrasyid. 2007. The True Power of Love: Kitab Para Pecinta Allah. Bandung: Mizan Pustaka.

Salam, Aprinus. 2004. Oposisi Sastra Sufi. Yogyakarta: Lkis.

Schimmel, Annemarie. 2008. Mystical Dimension of Islam. Kuala Lumpur: Academe Arts and Printing Services.

Schrieke, B.J.O. 1973. 2009. Pergolakan Agama di Sumatera Barat. Jakarta: Bhratara.

Shalikin, Muhammad. 17 Jalan Menggapai Mahkota Sufi Syekh Abdul Qadir al-Jailani. Yogyakarta: 
Mutiara Media.

Shafadi. 2000. al-Wafi bi al-Wafayat. Beirut: Daar Ihya al Turas, Vol 3.

Siradj, Agiel. Januari 2000. "Perkembangan Tasawuf dalam Islam", Jurnal Media, IAIN Wali Songo Semarang, Edisi 32. Th. IX.

Smith, Margaret. 2010. Rabi'ah The M ystic and Her Fellow-Saint in Islam. New York: Cambridge University Press.

Sutiasumarga, Males. 2001. Kesusastraan Arab Asal Mula dana Perkembangannya. Jakarta : Zikrul Hakim.

al-Syarif, Muhammad Ibn Hasan Ibn 'Aqil Musa. 2000. Tasbih wa-M unajat wa Thana' ‘ala Ardh wa al-Sama'. Riyadh: Dar al-Andalus al-Khadhra'.

Yusuf, Abi. 1991. Maulid Barzanji. Surabaya: Anugerah.

Zaimul Am. 2008. Secret of The Secret: Hakikat Segala Rahasia Kehidupan. Bandung: PT. Serambi Ilmu Semesta. 